\title{
Addis Ababa Urbanism: Indigenous Urban Legacies and Contemporary Challenges
}

\author{
Elena Givental ${ }^{1}$ \\ ${ }^{1}$ Department of Anthropology, Geography, and Environmental Studies (AGES), California State University - \\ East Bay, Hayward, USA \\ Correspondence: Elena Givental, AGES, CSU-East Bay, Hayward, CA 94542, USA. Tel: 1-510-885-7558. \\ E-mail: elena.givental@csueastbay.edu
}

Received: December 29, 2016

Accepted: January 14, 2017 Online Published: February 24, 2017

doi:10.5539/jgg.v9n1p25

URL: http://dx.doi.org/10.5539/jgg.v9n1p25

\begin{abstract}
Addis Ababa, the capital of Ethiopia, has been experiencing rapid urbanization as the entire country has transformed into an emerging market economy featuring a spectacular average ten percent GDP growth rate over the last ten years. However, this economic growth has not provided a poverty elimination momentum for the city where over half of its residents still live in slum areas and over thirty percent are unemployed or involved in informal economic activity. This paper examines the factors behind Addis Ababa's inhibited urban progress focusing on urban legacies stemming from the city's one-hundred-thirty years of independent development as well as on the present-day economic challenges. The empirical evidence suggests that there is a correlation between Addis Ababa's inadequate investment in urban housing and infrastructure and Ethiopia's low levels of foreign direct investment. Further analysis indicates that the country's service-driven growth model of development may be contributing to overurbanization and poverty production in Addis Ababa.
\end{abstract}

Keywords: Addis Ababa, Ethiopia, overurbanization, service-driven development, slum production, urban legacies

\section{Introduction}

\subsection{Defining the Problem}

Addis Ababa, the tenth largest city in Africa, is the capital of Ethiopia, the country that has never been colonized. It is a city of immeasurable contrasts in wealth and poverty, splendor and scarcity. It is home to Addis Ababa University, museums, churches, foreign embassies, and the super-modern building of the African Union Headquarters. On the other hand, it is an embodiment of the country where an average citizen earns $\$ 600$ per year, over fifty percent of urban residents live in slums, and only fifteen percent of the roads are paved. The abundance of women and children begging in the streets is an eye-catching attribute of the Addis Ababa cityscape, contrasting to the magnificent churches and embassy campuses. While most of the existing scholarship on African urbanization and urban processes is concerned with the consequences of colonialism and post-colonial past-dependent development, Addis Ababa represents an interesting case of non-colonial urbanism. Therefore, the issue in focus is identifying the roots of factors responsible for the convergence of urban attributes manifested by both post-colonial and independently-developing African cities. Addis Ababa serves as an applicable case study for the latter cause.

\subsection{Heritage Urbanism in the "Majority World"}

Most twentieth century theoretical work on cities has been based on the urban experiences and realities of metropolitan areas in North America and Europe. Today, the center of twenty-first century urban theory has moved to the developing world where most urban growth is now occurring (Roy, 2009). Urban development in various regions of the world has been receiving different facets of scrutiny and emphasis. While Latin American urban theories have been focused on dependency and South Asian theory on urban redevelopment and inequality, the scholarship on East Asia has been concerned with economic globalization and cultural cosmopolitanism. For a while African urban studies have been echoing the Latin American themes on dependency, underdevelopment, and informalization; however, more recently the focus has moved over to understanding market development and modernity in African cities, to viewing them not as "failed" cities but as the cities of aspirations and 
expectations (Roy, 2009, 823). While on the surface most urban practices in the developing countries are of survival and necessity, at the same time the "alternative urbanism" holds the promise of development of a different, better city (Vasudevan, 2015). Modernity, once viewed as the experiences of Paris, London, Vienna, Chicago, New York, or Los Angeles, today is seen everywhere. Contrary to the idea that cities in the developing countries are somewhat "backward" and "underdeveloped", today there is a sense of the "contemporariness" and "worldliness" of African cities that can tell something profound about all cities in the world (Roy, 2009).

An essential feature of current urbanization in developing countries is that it appears to be decoupled from the industrialization process while the proportion of people employed in formal economy continues to decline. Informality today is the primary form of organization of the twenty-first-century metropolitan space in developing countries (Roy, 2009, 826). In African cities, informality often becomes a way of operating more resourcefully in an under-resourced environment. A strong trend towards informalization in Africa results in an overall growth of informal activity, but especially in the growth of informal settlements. It has also been noted that there is connectivity between formal and informal settlements as well as between formal and informal employment (Roy, 2009; Myers, 2011). Furthermore, researchers find a relationship between capital investment per capita in colonial Africa and slum incidence: the settler colonies of Southern Africa (contemporary Namibia, South Africa, and Zimbabwe) that received relatively high levels of investment due to economic and political reasons have lower slum incidence than those countries developing under indirect colonial rules where urban settlements received lower investment and were managed with ad hoc institutions (Fox, 2014).

One of the major reasons for the rapid uncontrollable growth of urban population, often termed "overurbanization" or "pseudo-urbanization", lies in the rising inequality between rural and urban areas that continues to attract rural population into cities (Yeh, Yang, \& Wang, 2015). Because contemporary cities in developing countries often grow in spite of poor microeconomic performance and without significant foreign direct investment and proper governmental regulations, urban authorities are unable to provide adequate basic infrastructure or essential services (Cohen, 2006). Consequentially, since the 1970s, the slum growth has outpaced urbanization (Seabrook, 2007). Contrary to a common belief that slum incidence is a transitional phenomenon as a product of slow market expansion and insufficient accommodation of labor migrants, the latest studies indicate that the persistence of slums is more likely to be attributed to land and housing market failures arising from economic and institutional weaknesses (Fox, 2014). From that standpoint, a country's colonial past plays a less important role in the production of modern urbanism than today's legal land ownership and institutional strength factors.

Three major factors usually account for city growth in a developing country: rural-urban migration, natural population increase, and changes in urban allocations, in that order of importance. Lack of investment, manufacturing job deficit, marginalization of migrants, and poor city planning, accompanying the "overurbanization" process, create the perfect-storm conditions for the expansion of urban slums. Contrary to the common impression of slums as exclusively informal settlements, any urban area that is characterized by some combination of tenuous dwelling structures, lack of access to adequate water and sanitation facilities, overcrowding, and insecure tenure, formal or informal, is considered a slum area (UN-Habitat, 2010; Fox, 2014). In African cities, specifically, colonial-time marginalization of local population, colonial planning, or post-colonial attempts to literally move capital cities to subvert the colonial legacies are considered to be the major sources of informality and slum production (Myers, 2011, 46, 69).

According to the UN-Habitat (2010), over 800 million people in Africa, Asia, and Latin America lived in slums by the end of the twenty-first century's first decade. Sub-Saharan Africa has the highest slum incidence, with 61.7 percent of urban residents living in the sub-standard housing conditions. The $2010 \mathrm{UN}$-Habitat study showed that all over the world the number of slum dwellers had been decreasing, with the projected 227 million people moving out of slum areas between the years 2000 and 2010 thus almost doubling the slum target of Millennium Development Goal Number Seven (UN-Habitat, 2010). The bad news for Sub-Saharan Africa, however, was that the total proportion of people living in slums in this region had decreased by only five percent.

The most recent research indicates that the numbers of the world's poor, including slum inhabitants, have been largely underestimated. According to the latest estimates, Sub-Saharan African cities have twenty to forty million slum dwellers that have not been counted in the latest government censuses (Carr-Hill, 2013). The systemic underestimation of the urban destitute and underprivileged resident numbers results in inefficient urban policies and over-inflated progress toward the United Nations' Millennium Development Goals (World Development Indicators, 2014). The latter claim may explain vast discrepancies in the reported proportion of Ethiopia's urban population residing in the slum areas. The report numbers, depending on the methods of estimation and the guidelines accepted for the delineation of slums, range from sixty percent to eighty percent, with even a larger 
range, from eighty-two percent to fifty-five percent, in Addis Ababa alone (UN-Habitat, 2008; UN-Habitat, 2010).

\section{Method}

This paper explores the historical and contemporary roots of the Addis Ababa urbanism focusing on the challenges that plague Addis Ababa and the possible solutions to the ailments. It is specifically concerned with the relationships between the inherited urban attributes, today's economic routes, and the outcomes that define lives of millions of urban residents in Addis Ababa. In this paper, I first describe the visible signs of inequality in the city that reveal both the spread of poverty and the accumulation of wealth. Second, I examine the historical roots of slum production in Addis Ababa in their divergence from the slum origins in many other African cities. Then, I move on to discussing the contemporary economic realities in Ethiopia suggesting their association with the continued production of poverty in the city. The convergence of urban traits found in Addis Ababa and in many other African cities, namely, overurbanization, slum production, and the spread of informalization, suggests that factors other than colonial past, may affect the cities' contemporary development. In conclusion, I summarize the lessons from the analysis of Addis Ababa urbanism to provide suggestions for the city's urban management and growth. The qualitative research was conducted during a three-week period of the participant observation in the field. The data used in this study is mainly empirical and is accompanied by the authentic photographic evidence. The conclusions are drawn on the basis of a combination of available statistics and the author's own observations and reflections.

\section{Results}

\subsection{Addis Ababa Cityscape: Wealth Intermingled with Poverty}

Addis Ababa, the capital of Ethiopia, is the tenth largest city on the African continent, with 3.4 million residents in the city proper and 4.6 million in the metro area (Ethiopia Population, 2015). It is Ethiopia's primate city hosting thirty percent of the country's urban population. Addis Ababa has been the ninth fastest growing African city, with a 4.1 percent growth rate between 1990 and 2006 (UN-Habitat, 2010). Its population has, in fact, tripled since 1980 but is considered largely underestimated (Adugna, 2008; Myers 2011, 52). The high rate of rural-urban migration accounts for around forty percent of this growth (UN-Habitat, 2010).

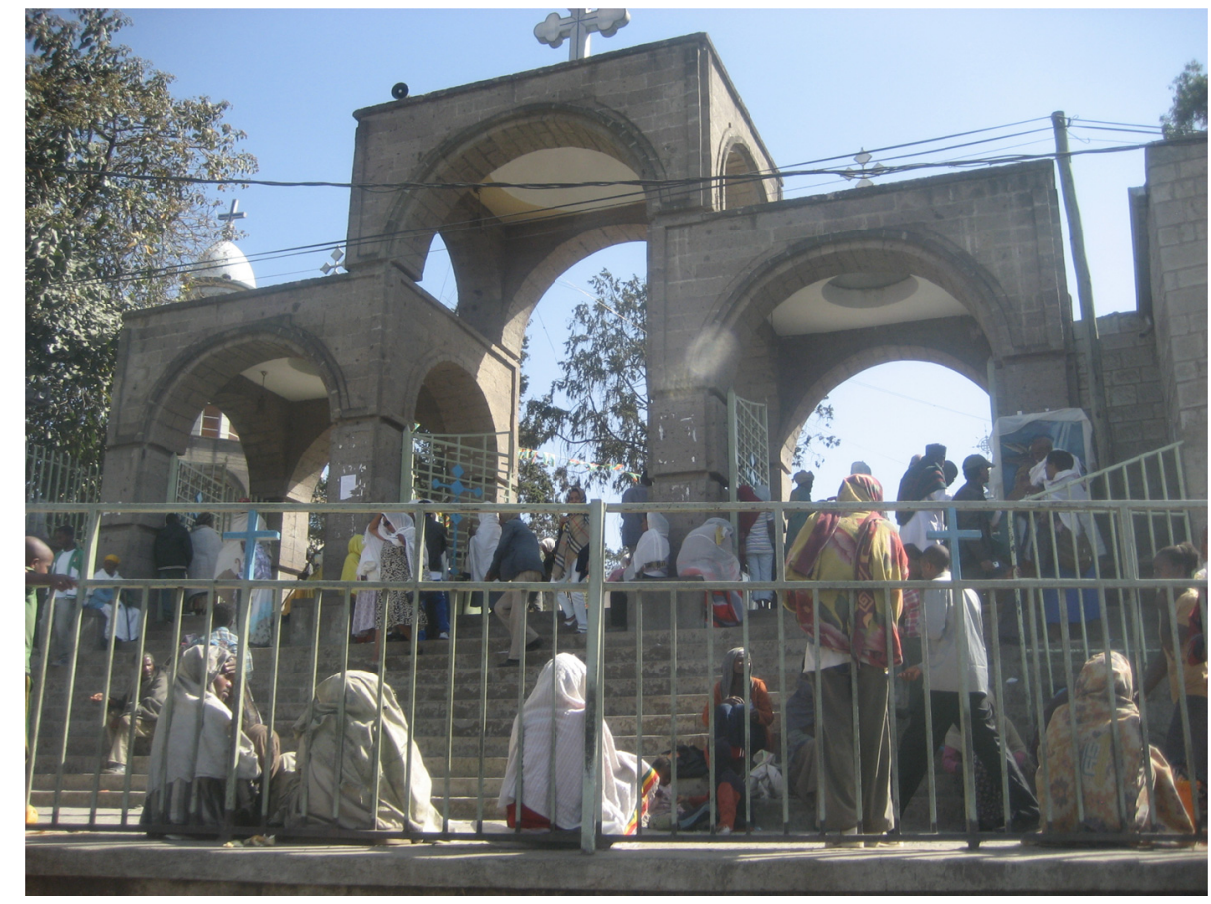

Figure 1. Asking for help at the church entrance, central Addis Ababa (photo by the author, January 2013)

Unlike many other African cities that bear the signs of their colonial heritage, Addis Ababa was founded in 1886 by the Ethiopian Emperor Menelik II who singlehandedly chose this site for his court (Palen, 1974). Being the capital of the second most populous country in Africa and the main administrative capital of the entire African 
Union, Addis Ababa presents a host of foreign embassies and the recently constructed Headquarters of the African Union, a two-hundred-million-dollar project donated by the Chinese government, constructed by the Chinese workers, and inaugurated in 2012. There are also Addis Ababa University founded in 1950 and currently enrolling forty thousand students, the National Museum of Ethiopia founded in 1958 as part of the Institute of Archeology and exhibiting the reconstructed skeleton of famous Lucy, our three-million-year-old female ancestor discovered in Ethiopia, and the Holy Trinity Cathedral built to commemorate the liberation of Ethiopia from the Italian occupation during WWII and now the burial place of the last Ethiopian Emperor Haile Selassie. Reflecting the country's religious sixty-forty percent split between the Christians (the majority being the Ethiopian Orthodox) and the Muslims, Addis Ababa exhibits a vast variety of churches and mosques.

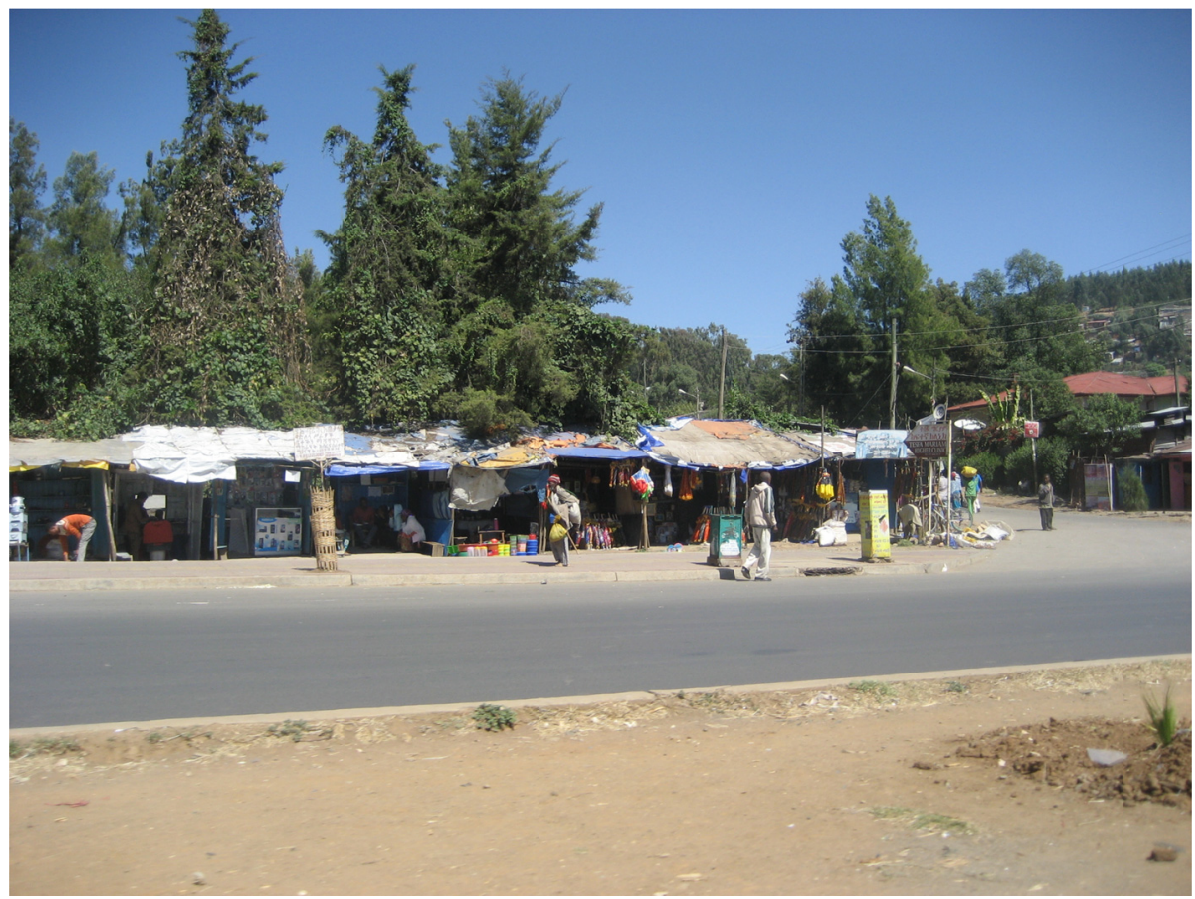

Figure 2. Informal businesses lining up one of the central streets in Addis Ababa (photo by the author, January 2013)

Notwithstanding this publicly displayed splendor, the city's another conspicuous feature is a sizeable number of destitute people, especially women and children, begging in the streets and at every church entrance (Fig. 1), and multitudes of small informal businesses (Fig. 2). Given the nature of the shadow economy, it is very difficult to make a quantitative assessment of the size of informal business in Addis Ababa; however, one of the few existing sources has estimated informal economy in Ethiopia to comprise 40.3 percent of the GNI in 1999/2000 (Schneider, 2002). According to the UN-Habitat studies (2008, 2010), unemployment rate among the city's residents reaches thirty-one percent. Addis Ababa is infamous for poor quality housing, infrastructure and sanitary development with estimated fifty-five percent of the city residents living in slums defined as overcrowded, below-standard quality formal or informal housing with inadequate access to safe running water and sanitation, often linked to economic and social marginalization (Davis, 2007; UN-Habitat, 2010).

African cities appear to be the most unequal in the world, with the ever-increasing gap between the rich and the poor (UN-Habitat, 2010). The recent poverty survey in Ethiopia found that the Gini coefficient, a statistical measure of income distribution ranging from zero indicating a perfect income equality to one indicating total inequality, has increased between the years 2000 and 2007 and has reached a value of 0.47 in urban areas compared to 0.27 in rural areas (Ali, 2011). Consumption Gini coefficient in Addis Ababa, according to the 2010 UN-Habitat study, was in the 0.50-0.59 range between 1998 and 2007. Moreover, Addis Ababa appears to cap the list of the most unequal cities in the world after Johannesburg with seven other South African cities and Goiana with other six cities in Brazil (UN-Habitat, 2010). In Addis Ababa's center, luxury villas behind tall solid walls topped with barbed wire (Fig. 3) intermingle with the blocks of slum housing (Fig. 4) presenting the optic evidence of this inequality. 


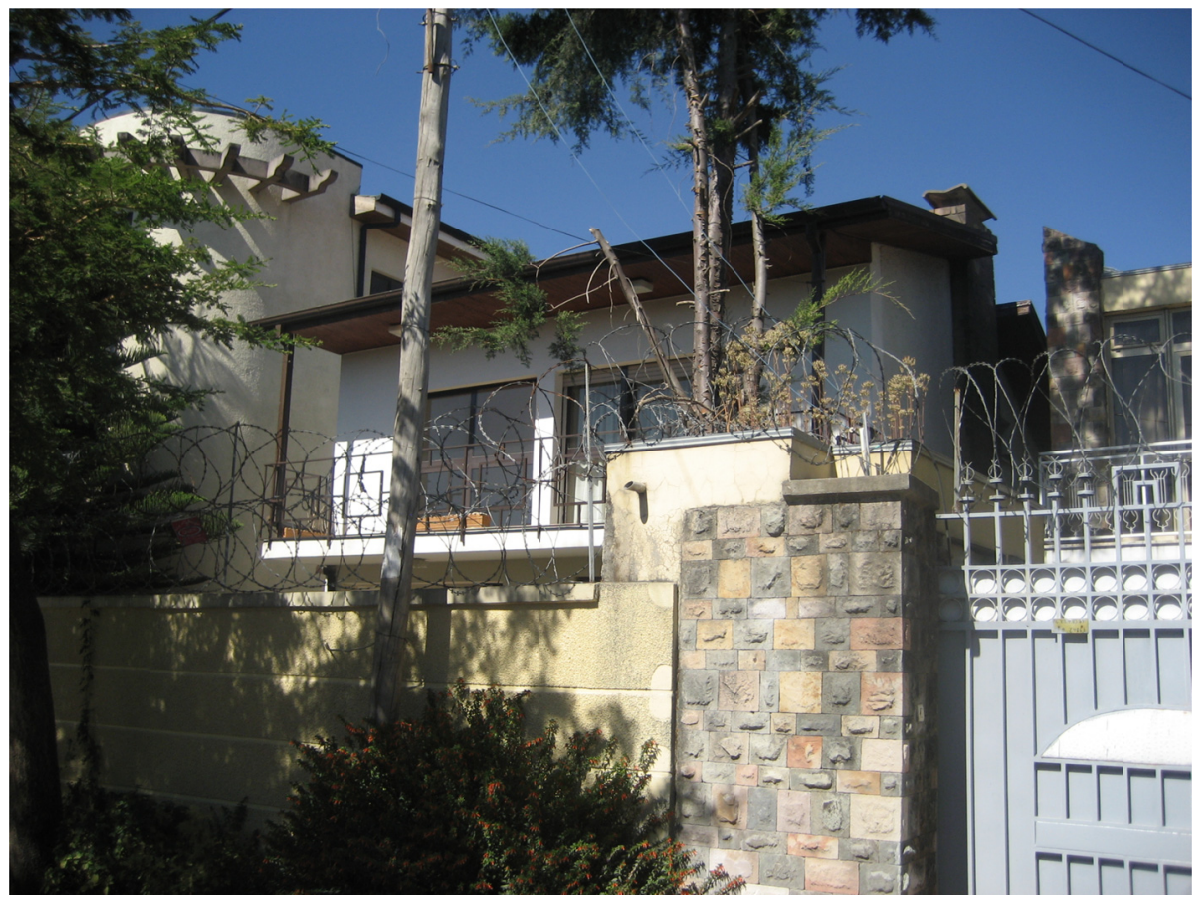

Figure 3. Exclusive single family houses in the Bole district, central Addis Ababa (photo by the author, January 2013)

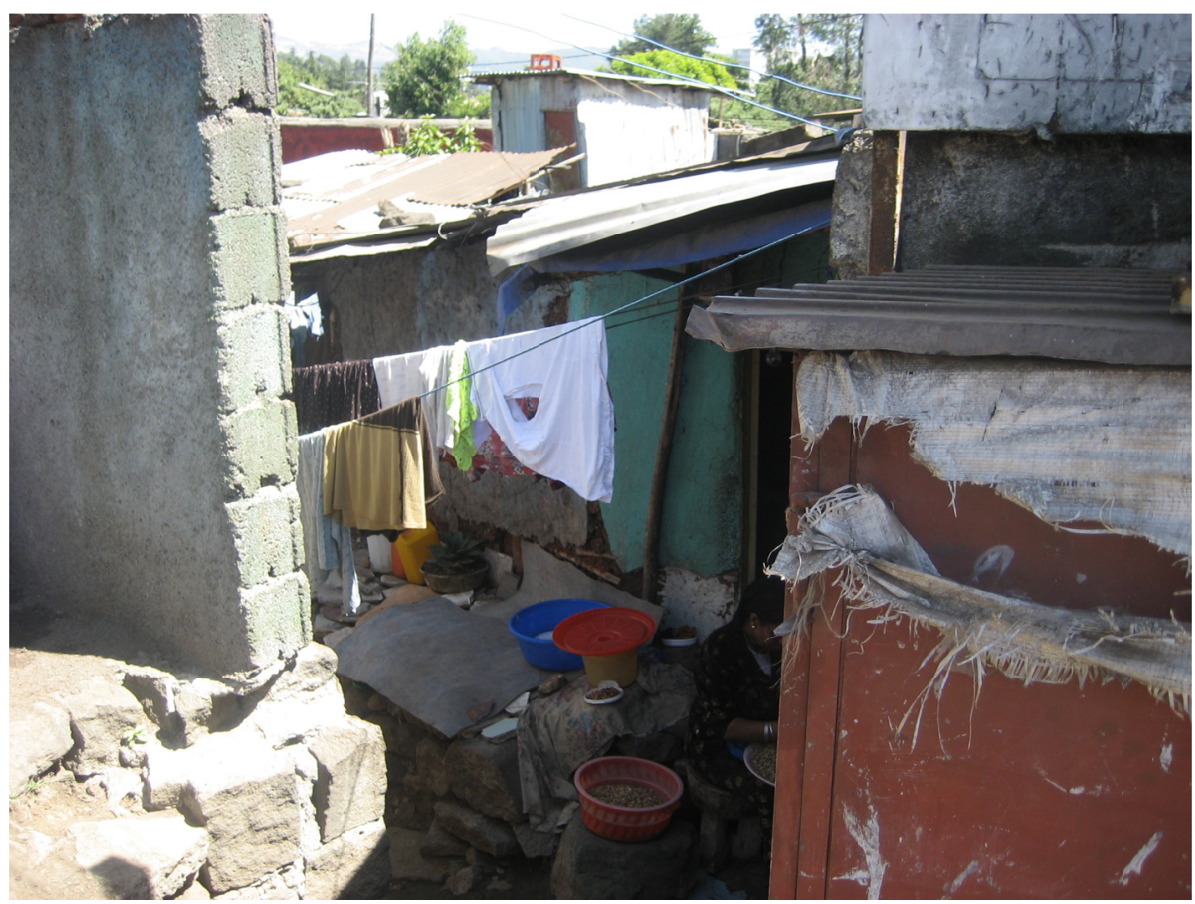

Figure 4. Slum housing in the Bole district, central Addis Ababa (photo by the author, January 2013)

In all fairness, Addis Ababa has its growing middle class, mostly small and medium business owners and young educated professionals working for international businesses and financial services, whose arrival is signaled by a fast growth of gated communities and apartment high-rises. According to the African Development Bank, thirty-four percent of African workforce was earning middle class incomes in 2010 compared to twenty-seven percent of Africans in 2000 (The Rise of Middle Class in Africa, 2013). Of course, these numbers differ from country to country, and the highest numbers of the middle class income earners are found not in Ethiopia but either in North or South Africa; however, in Addis Ababa this presently small group of residents has already 
initiated the remarkably visible changes in the cityscape driving the increase in advertisement and demand for pricey restaurants and shopping malls, purchasing luxury cars and apartments, and creating the uplifting feeling of unlimited possibilities and a momentum for progress.

\subsection{Addis Ababa's Urban Slum Producing Legacies}

Most research on urbanism in Africa was focused on the influence of the colonial-era infrastructure and governance over urban processes. Thus, the urban areas in British, German, Dutch, Belgian, French, Portuguese, and Italian colonies were found to display a significant dichotomy between colonizer and colonized zones and a clear distinction between "modern" and "traditional" cultures and economies (Myers, 2011). However, Addis Ababa presents a challenging case of urban slum production as it is falling out of a typical post-colonial slum narrative. Contrary to the bifurcation tendency of most African post-colonial cities, Addis Ababa is more uniform; however, this uniformity is expressed through a prevalence of slums. According to UN-Habitat (2008), almost eighty-two percent of the urban population in Ethiopia lived in slums in 2005, a much higher slum population incidence than the Sub-Saharan average of sixty-three percent at that time.

Addis Ababa, though founded at the height of urban colonial development in 1886, is an indigenous African creation built from scratch due to the decision of Emperor Menelik II to settle his court on this site (Palen, 1974). Started as an army campsite with scattered sefers (camps) around the emperor's palace, it had fifteen thousand permanent residents by 1889 while still featuring tents and temporary huts. The housing census of 1961 showed that most of the residential dwellings in the city were of very poor quality, with only 4.4 percent of the buildings having stone or concrete walls that are better suitable for the local climate conditions. Addis Ababa is located at the altitude over 2,300 meters (7,700 feet) above sea level in a monsoon climate region. The combination of high altitude and rainy summer season accounts for summer floods and relatively mild year-round temperatures ranging from $24^{\circ} \mathrm{C}\left(76^{\circ} \mathrm{F}\right)$ during the daytime to below $7^{\circ} \mathrm{C}\left(45^{\circ} \mathrm{F}\right)$ at night (Addis Ababa Climate and Temperature, 2016). The housing survey carried out in the early 1970s confirmed that the majority of the city residents lived in houses made of checa - a mixture of earth, straw, and water plastered around vertical eucalyptus support poles, with mud flooring and no permanent foundation (Palen, 1974). These structures provided over forty percent of the housing stock in the city. The system of feudal landownership that existed until 1974, the year marking the end of the last Ethiopia's Emperor Haile Selassie era, precluded the city's poor from having access to land. The result was an expansion of informal structures intermingled with formal housing of almost similarly poor quality. That kind of residential arrangement may have given rise to one of the largest slum incidences in Africa remaining the city's long-lasting legacy until today.

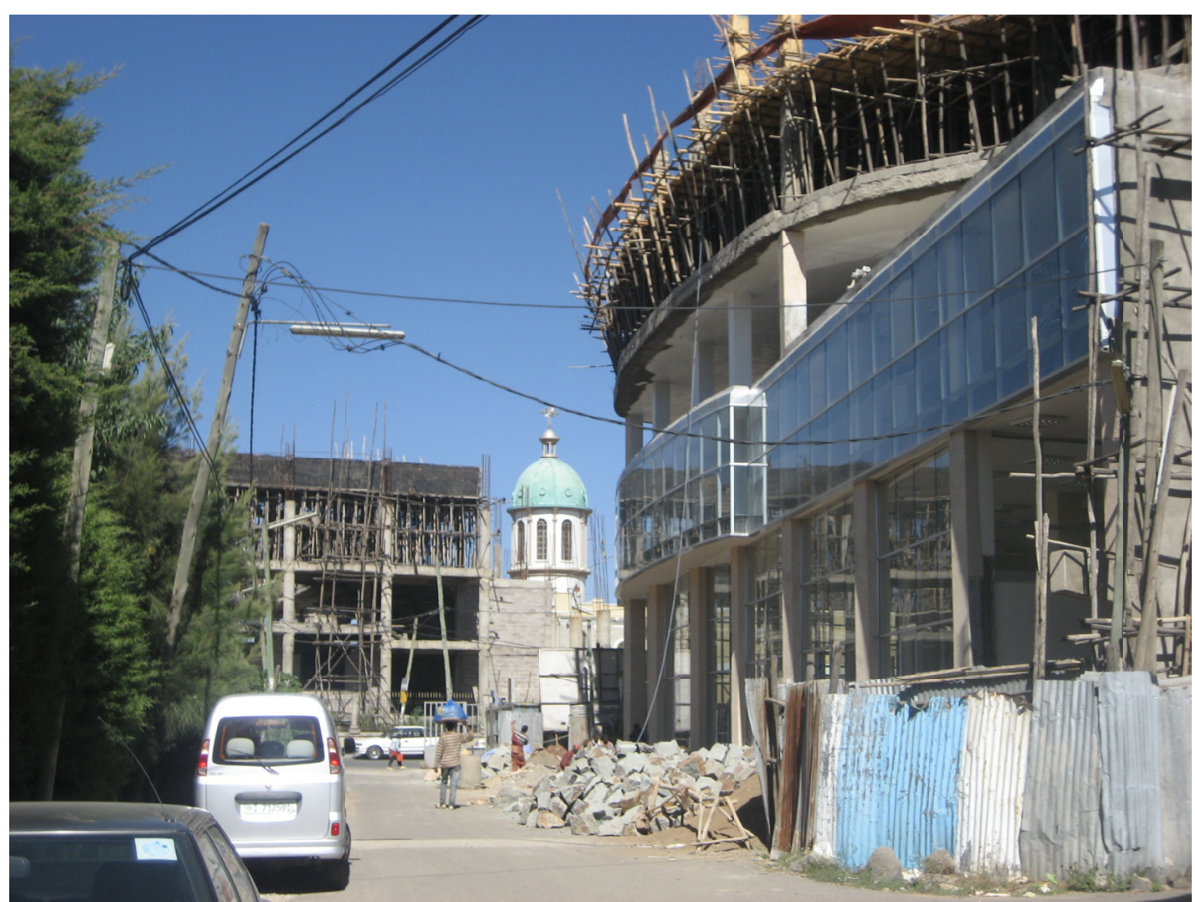

Figure 5. Unfinished residential and office buildings next to the Bole Medhane Alem Church, central Addis Ababa (photo by the author, January 2013) 
While the legacies of urban land use and distribution during the Emperor Haile Selassie's regime are still tangible in Addis Ababa, the later command economy's urban-shaping attributes can be also traced in today's Addis Ababa housing stock deficiencies. The Marxist, pro-Soviet military Derg government (the short name for the Coordinating Committee of the Armed Forces, Police, and Territorial Army), which was in power from 1974 till 1987, nationalized all land and property including rental houses. The kebeles, urban housing associations, served as low level administrative units that managed the housing stock. They, however, could not improve access to residential housing due to the overarching government landownership system. Following the Soviet Union footsteps, the centralized government cut rent by seventy percent that left little cash flow available for maintenance and construction. As a result, even twenty years after the demise of the Derg government, over forty percent of the former kebele houses needed replacement, and fifty to eighty percent of the remaining houses were informal (UN-Habitat, 2008). Today, the Ethiopian government still owns land and grants rental rights to the city residents. Twenty-nine percent of the formal dwellings have no separate room for cooking, and thirty-four percent of the residents use water from frequently interrupted public taps (UN-Habitat, 2008). The sanitation problem in Addis Ababa is one of the most acute as twenty-six percent of the formal houses (not including informal slums) have no toilets, an existing sewage system is outdated and inadequate, and thirty-five percent of the solid waste is never collected and thus dumped into ditches, rivers, roadsides, and other public spaces (UN-Habitat, 2008).

One of the most striking features of the Addis Ababa cityscape today is the extent of buildings under construction. The first impression is of a construction boom that suggests a positive dynamic momentum. At a closer look, however, many of these construction sites are half-finished office and apartment buildings that do not exhibit any signs of construction activity (Fig. 5). The Ethiopian government not only owns all land that is leased to private enterprises for a ninety-nine-year period; it also regulates prices of construction materials and company permits, access to financing and construction equipment. Private sector lending is restricted to short term loans with high annual interest rates while initial investment is required to comprise at least thirty-five percent of the estimated project's cost (Tesfahunegn, 1999). These strict regulations have been the main reason for the bulk of unfinished and often abandoned construction sites in Addis Ababa that create a peculiar impression of the city being in a permanent state of construction in progress. The chronic deficit of the most commonly used construction materials such as corrugated iron sheets and reinforced concrete slabs is an additional factor that determines delays in construction. The only construction material that seems to be in good supply is eucalyptus round wood used for scaffolding as well as for checa in low quality residential structures. The demand for the eucalyptus wood material supports one of the most common types of informal activities in the city usually carried out by women who can be seen hauling enormous piles of eucalyptus poles on their backs from the surrounding woods.

Due to the abundance of unfinished construction sites, the city air is polluted with suspended construction cement that poses a tangible health hazard, especially during dry winter months. Cement dust is mixed with unrestricted car exhaust, the second hazardous component of the city's air pollution due to the lack of exhaust regulations and the prevalence of used outdated automobiles in the streets. Most taxi cabs in Addis Ababa, popularly termed the "blue taxis", are old models of Lada, low quality automobiles that were built in the Soviet Union in cooperation with the Italian Fiat in the city of Tolyatti on the Volga River. Until recently, the city's public transportation demand was satisfied by the obsolete models of minivans, mostly former Soviet $R A F$ once manufactured in Latvia, or VW minivans, in equally bad shape. A ride in an overcrowded shared minivan-taxi is cheap even by the Addis Ababa standards.

Of course, not all projects in Addis Ababa remain unfinished. Shanty houses in areas such as Kirkos, Lideta, Arat Kilo, and Kazanchis have slowly started to give way to new apartment buildings. By 2012, one-hundred-forty thousand new condominiums were built by the government. The major problem, reported by the city residents, is the complete lack of infrastructure, such as sewage systems, paved roads, or green zones in the new housing project areas (Mestika, 2012). The latest residential construction project in Addis Ababa is termed 40/60. This project may produce better results as future residents will be asked to deposit forty percent of the house value in advance with the remaining sixty percent to be covered by the government as a long term loan to residents. This project, however, might be available only to the newly forming Addis Ababa middle class thus again leaving the current slum residents behind.

Another example of a result-producing construction-in-progress is the first in Sub-Saharan Africa Addis Ababa light rail, the initial two lines having opened in the fall of 2015 (Addis Ababa Light Rail, 2016). The construction shut down traffic on all major city roads for at least four years but resulted in a seventeen-kilometer (eleven-mile) line connecting Mercato, the main city market, and Meskel, the central square, with the industrial park in the south 
of the city, with the total of thirty-two stations on the way. The rail project was financed by the Export-Import Bank of China and constructed by the China Railway Group company. It is currently operated by the Shenzhen Metro Group (Addis Ababa Light Rail, 2016). Chinese capital today comprises the major investment inflow in Ethiopia, both in transportation and manufacturing. While virtually all road construction projects are outsourced to the Chinese companies, the largest industrial park south of metro Addis Ababa is also mainly represented by the Chinese investment in Ethiopian leather and shoe manufacturing (Jobson, 2013).

\subsection{Addis Ababa in the Context of Ethiopia's Economic Transition}

In 2007, for the first time in history, half of the world's population was living in urban areas. In Sub-Saharan Africa, the proportion of urban population is estimated to have risen from just ten percent in 1950 to over thirty-five percent at the beginning of the twenty-first century (Leon, 2008). In absolute terms, Africa's urban population is projected to more than double, from 295 million in 2000 to 748 million in 2030 (Cohen, 2006). Ethiopia, where still only nineteen percent of the population is urban (World Bank, 2015b), has been progressively urbanizing too. Thus, the population of Addis Ababa experienced a 6.8 times increase between 1952 and 2007, the year of the latest population census. While the Addis Ababa residents made up only one percent of the country's population in 1952, they already comprised 3.7 percent of the total in 2007 (estimated from Palen, 1974; The 2007 Population and Housing Census of Ethiopia, 2007). Addis Ababa is, in fact, one of these contemporary cities where informal activities and slum production coexist with modernity and creativity. It is usually the first impulse of a researcher to blame the historical vestiges of colonialism and oppression for our modern pains. However, in order to better understand the challenges of the city's contemporary development, the scrutiny should be directed not only at the Ethiopia's path-dependent housing legacies stemming from the landownership systems of the imperial and Derg eras but also at today's economic processes.

Ethiopia is a developing country that has been in transition from command to market economy since 1991, after the abolition of the Soviet-backed Marxist-oriented Derg regime and the ousting of the dictator Mengistu who fled to Zimbabwe. Although never formally colonized by any European power, Ethiopia experienced a relatively short Italian occupation between 1939 and 1941. Today Ethiopia is a federal parliamentary republic headed by a prime minister with the first democratic constitution adopted in 1995. The Ethiopian economy has experienced a staggering average annual GDP growth rate of 10.8 percent over the last fifteen years, placing it among the ten fastest growing economies in the world. In spite of this spectacular growth, Ethiopia is still one of the world's poorest countries, ranking two-hundred-eleventh out of two-hundred-twenty-nine countries based on its GDP per capita and classified by the World Bank (2015a) as a low-income economy with $\$ 470$ GNI (Gross National Income) per capita. Over sixty-six percent of the Ethiopian population lives below $\$ 2$ per day (World Bank, 2015b).

Since 1991, Ethiopia has come a long way from a command economy to a democratically-governed developing country. Market reforms, however, have not been consistently successful in Ethiopia and have not equally benefited the majority of the population, as reflected in its socio-economic indicators. While eighty-one percent of the population is still rural, only forty-two percent of the rural population has access to clean water. The HDI (Human Development Index), estimated as a complex statistical indicator combining income per capita with the country's educational level and life expectancy, is 0.442 on the scale from zero to one (List of Countries by Human Development Index, 2016) that is low even by the development country standards though it had been showing a steady improvement over the last several years (World Bank, 2015b). Why has not the extraordinarily high GDP growth rate translated into poverty reduction over the last two decades? The explanations may lie in Ethiopia's development model which favors the service sector expansion at the expense of manufacturing and in the inadequacies of the agricultural sector that still employs over eighty-five percent of the population but suffers from political and environmental quagmires resulting in the increasing rural-urban migration and ensuing overurbanization of the Ethiopia's primate city.

Ethiopia's agriculture, in spite of being the country's major economic sector accounting for 46 percent of Ethiopia's GDP, is marred by the recurrent droughts, the prevalence of small plots, increased government taxation on fertilizers, and lack of technological innovations. Coffee, the major agricultural cash crop in Ethiopia, has seen highly volatile prices with a tendency of decrease in the last decade. One of the major problems is Ethiopia's land tenure laws. All land is state-owned and individual families must pay annual governmental tax on using land for farming. Each successive generation of male descendants obtains parcels of land from their parents thus gradually decreasing the overall size of plots for each family (Hunnes, 2012a). Decreasing plot size alongside increasing land and fertilize input taxation and shortage of rainfall are the major drivers of rural-urban migration in Ethiopia. According to the latest survey of low-skilled laborers in Addis Ababa who had migrated from the rural areas (Hunnes, 2012b), the most commonly cited reasons for migration were inability to grow 
enough food or other agricultural products from their small plots and the need for more money and job opportunities. Unequal access to and inefficiency of such government programs as the Productive Safety Net Program (PSNP) designed to protect the poorest rural families during the times of droughts and other hardships, was also cited as one of the reasons for economic migration to the city. Unskilled and often illiterate rural migrants arriving in Addis Ababa usually find temporary low wage laborer jobs as shoe shiners, concession and lottery ticket sellers, and car washers, or resolve to begging in the streets, generally losing the community support they used to have in their villages (Hunnes, 2012b).

Ethiopia's service industries represented by the largest and the most successful airline in Africa, Ethiopian Airlines, and a fast-growing financial sector, account for forty-three percent of the GDP share; however, this value-adding activity has not resulted in a significant job creation. According to the same statistics, forty-three percent of the GDP value is created by only ten percent of the workforce. Ethiopia's service sector lacks such essential ingredients as a well-integrated domestic market, skilled labor force, and quality infrastructure necessary to be globally competitive in the areas of financial services or tourism (Ali, 2011) that today have become the major job creating agents in many developing countries. As it has been observed in other developing countries, service economy leads to social stratification and the increasing gap between the rich and the poor (Yeh et al., 2015).

The stunted job creation spurred by the service-driven growth model may also be the result of an extremely low level of foreign direct investment (FDI) accounting for only 0.8 percent of the country's Gross Domestic Product (GDP). FDI in Africa has gone from $\$ 15$ billion in 2002 to $\$ 37$ billion in 2006 and $\$ 46$ billion in 2012; however, most of the capital inflows went to Northern and Western African countries (A Hopeful Continent, 2013). Ethiopia, while fundamentally dependent on import of most manufactured goods, has been largely excluded from the flow of global FDI (Reinert, 2007; World Bank, 2015b). Though Ethiopia did experience a significant FDI inflow increase since 1992 starting literally from a zero after the collapse of the pro-communist Derg regime, the annual capital investment in Ethiopia has been measured not in millions but in thousands of dollars. In contrast, the capital inflows to most of the fast developing export-oriented economies of East-, South-, and Southeast Asia have been thousands or even millions of times higher. Thus, while Ethiopian accumulated FDI as of 2013 was a meager $\$ 4.37$ million, China accumulated \$574 billion, India \$191 billion, and Vietnam \$78 billion (Ethiopia, 2016).

There are several possible reasons for the low FDI inflows in Ethiopia. One of the reasons is education poverty, especially primary education completion rate that, in spite of the long-term upward trend, remains below average for Sub-Saharan Africa (Reinert, 2007). Low educational level generally translates into lack of management skills and, consequentially, lack of human capacity to absorb FDI (Henze, 2003). Governmental policies of protectionism, an underdeveloped banking system subject to political pressure, and overarching bureaucracy and corruption are other commonly cited reasons that preclude international companies from investing in the Ethiopian economy (Henze, 2003; Robertson, 2009). The prevalence of small businesses, mostly consisting of sole proprietors, partnerships, or privately held corporations is not conducive to a massive foreign direct investment inflow (Robertson, 2009).

\section{Discussion: Past Dependence Is Not a Destiny After All}

Scholarship on urbanism in the developing world usually revolves around the marginalization of the poor as a result of the colonial path dependence and in the conditions of globalization of the world economy. Urbanization in Addis Ababa, however, defies many accepted canons by stemming from independent non-colonial development and almost two decades of the command economy. Ethiopia, while having finally joined the global economy, still lacks the same level of foreign investment and manufacturing as many other developing countries have achieved. The parallel urbanization traits in developing country cities on all continents represented by high slum incidence, growing income and consumption inequality, poor infrastructure, and hazardous pollution levels, may or may not be the result of market expansion and globalization or colonial past. The convergence of these attributes today recounted and analyzed in all large and medium cities of the developing world calls for finding a common denominator underlying this convergent development. This common denominator is more likely to be poor governance in the conditions of autocratic administration (be it the Emperor, the military socialism-oriented regime, or a corrupt ruling-party autocracy), resulting in lack of investment in public sphere and, too often, lack of interest in doing so due to shifting economic priorities to militarization and self-gratification. One exception to this pattern has been described in China where the ruling party, while having the power to control the flow of rural migrants into the largest cities, has been providing incentives to place industries in the rural areas thus managing to avoid the process of overurbanization, often referred to as "pseudo-urbanization" (Yeh et al., 2015).

Managing urban growth in Africa has become one of the most urgent challenges of the twenty-first century that 
has been made evident by the recent African Economic Outlook 2016 report released by the African Development Bank Group focusing on the issues of structural transformations in sustainable cities (African Economic Outlook, 2016). The Ethiopian economic momentum presents an opportunity to eradicate or at least to reduce urban poverty while the main challenges lie in the lack of urban jobs and capital investment necessary for urban projects. The Ethiopian government has demonstrated an undisputable leadership and determination by almost unilaterally subsidizing the construction of the Grand Ethiopian Renaissance Dam (GERD) on the Blue Nile, the largest hydropower project in Africa. The GERD is funded by the government bonds with additional $\$ 1.8$ billion in turbines and associated equipment financed by the Chinese banks. The GERD is the centerpiece of the government's proclaimed goal to "lift the population at large out of poverty before 2025" (Veilleux, 2013, 5). The dam has become part of Ethiopia's emerging mood of uplifting optimism and momentum which are expected to unify the country through economic development (Meredith \& Givental, 2016). Unfortunately, capital is scarce for less grandiose projects such as residential and urban infrastructure investment. Some signs of the Addis Ababa urban improvements are visible in the arrival of the first light rail lines, and the growth, though often stunted, of residential and office buildings. Ethiopia's service-driven model of development creates much fewer jobs than any known industrialization model, be it import substitution or export-oriented development. While the former model requires a larger, better developed domestic market than is present in Ethiopia today, the latter model entails governmental promotion of foreign direct investment inflows. Ethiopia's agricultural inefficiency and outdated land tenure laws serve as push factors for rural-urban migration thus exacerbating Addis Ababa's need for job creation.

This study attempts to find the relationships between the historical legacies, contemporary economic path, and current urban issues. With the evidence of a long-lasting connection between the earlier landownership systems and the production of slums in Addis Ababa, the lingering question of why Ethiopia's exemplary consistent GDP growth rate over the last decade has not translated into poverty reduction still exists. The examination of the latest economic developments reveals the lack of capital investment and insufficient manufacturing job creation as the main culprits of poor urban infrastructure and restricted housing construction progress in the capital city. While investigating the reasons for the government's inability or unwillingness to attract significant amounts of FDI was out of the scope of this study, the available data indicate the link to the government's protectionist policies and control over the financial system. Some other reasons may include administrative corruption as the leftover of the command economy, lack of economic freedoms resulting from the direct state control, lack of human capacity due to the low educational level of the majority of population, and network of small businesses that are unable to attract large capital inflows. While these FDI entry barriers keep most foreign investors at bay, the largest capital inflow arrives from the Chinese government and Chinese private companies that have been aggressively investing in African manufacturing and infrastructure development without creating sufficient amount of local jobs or transferring much of technology or know-how (Adem, 2012, 152).

Successful urban management is a complex task that can be resolved only by prudent capital investment in the conditions of transparent and efficient governance. The three pillars of urbanism are education, housing, and infrastructure development; however, they cannot be achieved without long-term planning, efficient economic policies, and momentum. Addis Ababa's urban development process has created a city in constant redefinition, a city of modernity as well as of poverty. Everyone who visits Addis Ababa feels the excitement of this momentum followed by the disappointment of inertia and inefficiency. The convergence of Addis Ababa's urban attributes with those of many post-colonial African cities suggests an evident link between urban production of poverty and inefficient governance resulting in lack of investment in public education, housing and infrastructure. While unprecedented economic growth creates a positive uplifting momentum for Ethiopia, it should create conditions for its capital city to fight poverty through increased investment in residential construction, equal education opportunities, promotion of foreign investment, and creation of manufacturing jobs. New country-wide and city-specific urban policies are essential for completing these tasks.

\section{Acknowledgements}

A version of this paper was presented at the International Geographical Congress in Beijing (PRC) in August 2016. I would like to thank the National Science Foundation and the American Association of Geographers for the generous AAG-NSF Travel Grant.

\section{References}

Addis Ababa climate \& temperature. (2016). Retrieved from http://www.addis-ababa.climatemps.com

Addis Ababa light rail. (2016). In Wikipedia, the free encyclopedia. Retrieved October 30, 2016, from https://en.wikipedia.org/wiki/Addis_Ababa_Light_Rail 
Adem, S. (2012). China in Ethiopia: Diplomacy and economics of sino-optimism. African Studies Review, 55(1), 143-160. http://dx.doi.org/10.1353/asw.2012.0008

Adugna, A. (2008). Lesson 2: Population data sources. Retrieved from http://www.ethiodemographyandhealth.org/Chapter_2_Population_Data_Sources.pdf

African economic outlook. (2016, March 23). Sustainable cities and structural transformation. Retrieved from http://www.africaneconomicoutlook.org/en/chapter/sustainable-cities-and-structural-transformation

A hopeful continent. (2013, March 2). The Economist: Special Report. Retrieved from http://www.economist.com/news/special-report/21572377-african-lives-have-already-greatly-improved-over-past -decade-says-oliver-august

Ali, S. (2011). Ethiopia's imperfect growth miracle. Carnegie Endowment for International Peace. Retrieved from http://[www.carnegieendowment.org/2011/10/20/ethiopia-s-imperfect-growth-miracle/8knh

Carr-Hill, R. (2013). Missing millions and measuring development progress. World Development, 46, 30-44. http://dx.doi.org/10.1016/j.worlddev.2012.12.017

Cohen, B. (2006). Urbanization in developing countries: Current trends, future projections, and key challenges for sustainability. Technology in Society, 28, 63-80. http://dx.doi.org/10.1016/j.techsoc.2005.10.005

Davis, M. (2007). Planet of slums. New York, NY: Verso.

Ethiopia. (2016). In The World Factbook. Retrieved from http://www.cia.gov/library/publications/resources/the-world-factbook/geos/et.html

Ethiopia population. (2015). World Population Review. Retrieved from $\mathrm{http}: / /$ worldpopulationreview.com/countries/ethiopia-population

Fox, S. (2014). The political economy of slums: Theory and evidence from Sub-Saharan Africa. World Development, 54, 191-203. http://dx.doi.org/10.1016/j.worlddev.2013.08.005

Henze, P. (2003). Reflections on development in Ethiopia. Northeast African Studies, New Series, 10(2), 189-201. http://dx.doi.org/10.1353/nas.0.0001

Hunnes, D. E. (2012a). Understanding rural-to-urban migration in Ethiopia: Driving factors, analytical frameworks, and recommendations. Journal of Global Health Perspectives, 1-10. Retrieved from http://jglobalhealth.org/article/understanding-rural-to-urban-migration-in-ethiopia-driving-factors-analytical-fra meworks-and-recommendations-2/

Hunnes, D. E. (2012b). An analysis of Ethiopian rural-to-urban migration patterns from primary interviews. Journal of Global Health Perspectives, 1-10. Retrieved from http://jglobalhealth.org/article/an-analysis -of-ethiopian-rural-to-urban-migration-patterns-from-primary-interviews-2/

Jobson, E. (2013, April 30). Chinese firm steps up investment in Ethiopia with 'Shoe City'. The Guardian. Retrieved from http://www.guardian.co.uk/global-development/2013/apr/30/chinese-investment-ethiopia-shoecity

Leon, D. A. (2008). Cities, urbanization and health. International Journal of Epidemiology, 37, 4-8. http://dx.doi.org/10.1093/ije/dym271

List of countries by Human Development Index. (2016). In Wikipedia, the free encyclopedia. Retrieved November 1, 2016, from http://en.wikipedia.org/wiki/List_of_countries_by_Human_Development_Index

Meredith, D., \& E. Givental. (2016). Hydro-politics and hydro-economics: Comparing upstream and downstream challenges for Vietnam and Ethiopia. The APCG Yearbook, 78, 148-167.

Mestika, R. (2012, November 13). Condominiums in Addis Ababa: Slums in the making? Addis Standard. Retrieved from http://addisstandard.com/condominiums-in-addis-ababa-slums-in-the-making/

Myers, G. (2011). African cities: Alternative visions of urban theory and practice. London - New York: Zed Books.

Palen, J. J. (1974). Housing in a developing nation: The case of Addis Ababa. Land Economics, 50(4), 428-434. http://dx.doi.org/10.2307/3145012

Reinert, K. (2007). Ethiopia in the world economy: Trade, private capital flows, and migration. Africa Today, 53(3), 65-89. http://dx.doi.org/10.2797/AFT.2007.53.3.64

Robertson, D. C. (2009). Corporate social responsibility and different stages of economic development: 
Singapore, Turkey, and Ethiopia. Journal of Business Ethics, 88, 617-633. http://dx.doi.org/10.1007/s10551-009-0311-x

Roy, A. (2009). The 21st-century metrolopis: New geographies of theory. Regional Studies, 43(6), 819-830. http:dx.doi.org/10.1080/00343400701809665

Schneider, F. (2002, July 17). Size and measurement of the informal economy in 110 countries around the world. Discussion Paper presented at the Workshop of Australian National Tax Center, Canberra, Australia. Retrieved from http://www.econ.puc-rio.br/gfranco/Schneider_informal_economy.pdf

Seabrook, J. (2007). Reviews: Race and class. Institute of Race Relations, 49(3), 88-110. http://dx.doi.org/10.1177/0306396807085905

Tesfahunegn, A. (1999). Construction in Ethiopia. Lunds Tekniska Högskola. Retrieved from http://www.lth.se/fileadmin/hdm/alumni/papers/icm1999/icm1999-10.pdf

The 2007 population and housing census of Ethiopia. (2007). Statistical report at national level: Central Statistical Agency. Retrieved from http://www.sca.gov.et

The rise of the African middle class. (2013, June 3). African Review. Retrieved from http://addisababaonlime.com/the-rise-of-the-african-middle-class

UN-Habitat. (2010). State of the World's Cities 2010/2011: Bridging the Urban Divide. Nairobi, Kenya: United Nations Human Settlement Programme. Retrieved from https://sustainabledevelopment.un.org/index.php? page $=$ view \& type $=400 \& \mathrm{nr}=1114 \&$ menu $=1301$

UN-Habitat. (2008). Ethiopia: Addis Ababa Urban Profile. Nairobi, Kenya:United Nations Human Settlement Programme. Retrieved from http://unhabitat.org/books/ethiopia-addis-ababa-urban-profile/

Vasudevan, A. (2015). The makeshift city: Towards a global geography of squatting. Progress in Human Geography, 39(3), 338-359. http://dx.doi.org/10.1177/0309132514531471

Veilleux, J. C. (2013). The Human security dimensions of dam development: The Grand Ethiopian Renaissance Dam. Global Dialogue, 15(2), 26-35. Retrieved from http://www.transboundarywaters.orst.edu_publications_publications_Veilleux_GLOBALDIALOGUE_V15_GE $\mathrm{RD}$

World Bank. (2015a). GNI per capita ranking. Retrieved from http://data.worldbank.org/data-catalog/GNI-per-capita-Atlas-and-PPP-table

World Bank. (2015b). World Development Indicators. Retrieved from http://data.worldbank.org/indicator/NY.GDP.MKTP.KD.ZG

World development indicators. (2014). Millennium Development Goals. Washington DC: International Bank for Reconstruction and Development / The World Bank.

Yeh, A. G. O., Yang, F. F., \& Wang, J. (2015). Economic transition and urban transformation in China: The interplay of the state and the market. Urban Studies, 52(15), 2822-2848. http://dx.doi.org/10.1177/0042098015597110

\section{Copyrights}

Copyright for this article is retained by the author(s), with first publication rights granted to the journal.

This is an open-access article distributed under the terms and conditions of the Creative Commons Attribution license (http://creativecommons.org/licenses/by/4.0/). 